\title{
KONCENTRACIJE TH1 I TH2 CITOKINA U MIKROCIRKULACIJI TUMORA I U SERUMU KOD BOLESNIKA SA SCLC I NSLC
}

\author{
Karlicic Vukoica, Stanojević Ivan, Sotirovic Jelena, Peric Aleksandar, Jović Milena, \\ Cvijanovic Vlado, Djukić Mirjana, Banovic Tatjana, Vojvodić Danilo
}

\begin{abstract}
Sažetak: Uvod. Rak pluća predstavlja jedan od najsmrtonosnijih zloćudnih tumora, uz minimalne ukupne stope preživljavanja bolesnika s uznapredovalom bolesti. Prema histološkoj strukturi se dele na SCLC i NSCLC. NSCLC se znatno razlikuju po biološkom ponašanju, kliničkom toku $i$ ishodukao $i$ odgovoru na terapiju. Od ranije je utvrđena važna uloga Th1 limfocita u anti tumorskom odgovoru, dok limfociti Th2 negativno utiču na zaštitnu reakciju.

Cilj. Naš cilj je bio da utvrdimo ključne Th1 $i$ Th2 citokine u mikrocirkulaciji tumora $i$ u uzorcima seruma, te da poredimo profil citokina kod bolesnika s plućnim tumorima različitih histoloških karakteristika.

Materijal i metode. U istraživanje je uključen 41 bolesnik sa tumorima pluća III i IV kliničkog stadijuma. Histološki tip je određen imunohistohemijski, a veličina tumora, lokalizacija i širenje bolesti određene su radiološki. IL-2, IL-12, IFN- , IL-4, IL-5, IL-6, IL-10 i IL-13 koncentracije su određene komercijalnim testovima protočnom citometrijom, u uzorcima seruma i mikrocirkulaciji tumora pluća.

Rezultati. Komparativnom analizom citokina u serumu bolesnika s rakom pluća je pokazala da bolesnici sa SCLC tumorima imaju značajnu koncentraciju IL-6 i IL-13. Bolesnici sa NSCLC imaju različite dominantne profile citokina. Uzorci kod pacijenata s NSCLC Ad sadržavale su visoke nivoe IL2, IFN- ,, IL-4, IL-10 i IL-13, pacijenti s NSCLC sq imaju visok IL-6 i IL-13, a pacijenti s NSCLC LC imaju visok nivo IL-2 i IFN- . Profil citokina u mikrocirkulaciji tumora, bio je potpuno različit od profila citokina u serumu. Uzorci iz tumora, kod bolesnika sa SCLC imaju visoke nivoe IL-12, IFN- , IL6 i IL-13. Pacijenti sa NSCLC su sa visokim nivoom IFN-- , IL-6 i IL-13, bolesnici sa NSCLC Sq su imali visoke vednosti IL-6 i IL-13, a bolesnici sa NSCLC LC imali visoke vrednosti IL-5 i IL-13. Analiza citokina u oba uzorka istog pacijenta je pokazala odnose tumor / serum koje su karakteristične za različite histološke tipova tumora. Kod bolesnila sa SCLC tumorom značajno je povećan odnos vrednosti IL-2, IL-12, IFN- , IL-4, IL-10 i IL-13 tumor / serum. Kod bolesnika sa Ad NSCLC značajno je povećana vrednost IL-12 i IL-6, kod bolesnika sa NSCLC sq povećana je vrednost IL-12 i IL-5, a NSCLC LC značajno povećana vrednost IL-5 i IL-13 kao i odnos vrednosti, tumor / serum.

Zaključak. Različiti histloški tipovi tumora pluća se razlikuju u pogledu nivoa Th1 $i$ Th2 citokina. Na osnovu koncentracije citokina u sistemskoj cirkulaciji $i$ mikrocirkulaciji tumora potvrđena je dramatična i značajna razlika.
\end{abstract}

\section{UVOD}

Rak pluća predstavlja jedan od najsmrtonosnijih malignoma, a manje od $15 \%$ ima petogodišnje preživljavanje od ukupno obolelih (1). Prema histološkim karakteristikama, karcinom pluća (LC) se deli na sitnoćelijski (SCLC) i nesitnoćelijski karcinom pluća (NSCLC) (2). Ove dve grupe tumora se ne razlikuju samo po histološkoj strukturi, razlikuju se i po biološkom ponašanju, kliničkom toku i ishodu, kao i po odgovoru na terapiju. Ćelije raka pluća su u stalnoj i dinamičkoj interakciji $\mathrm{s}$ imunim ćelijama, od nastanka maligne lezije do metastatske bolesti. Proučavanje Asselin-Paturel et al. bilo je među prvim koja su potvrdila značaj imunog odgovora u bolesnika s karcinomom pluća. Analizirali su mRNA za citokine u uzorcima tkiva, tumor-infiltrišućim limfocitima i limfocitima periferne krvi (3), kod 10 bolesnika $\mathrm{s}$ uznapredovalim NSCLC i pokazali su odsustvo mRNA za IL-2 i IL-4, IFN- $\gamma$ u prisustvu iGM-CSF mRNA, te bogatim prisustvom mRNA za IL-6, IL10 i TGF-b1. Oni su zaključili da lokalni i periferni imunološki odgovor kod bolesnika sa NSCLC je imao obeležja Th2 profil citokina. Iako je studija 
provedena na malom broju pacijenata i samo za jednu grupu tumora pluća, ovi podaci su važni jer su dokazali postojanje lokalne imunosupresivne reakcije i identifikovali su lokalne medijatore imunosupresije. Ti posrednici su proizvedeni i u tumorskm ćelijama i od infiltrišućih leukocita. Nekoliko studija je jasno pokazalo povećanje TGF$\beta 1$ u uzorcima bronchoalveolarne lavaže kod LC ili iz ćelijskih kultura tumorskih linija LC $(4,5,6)$. Tumorske ćelije su neosetljive na inhibitornu ulogu TGF- $\beta 1$ zbog gubitka funkcionalno specifičnih receptora (7), a lokalno i / ili tkivno proizvedenog TGF- $\beta 1$ koji negativno regulišu aktivnost NK čelija i CD8 + T limfociti, indukujući Th2 polarizaciju , diferencijacijaciju regulišućih T-ćelija (8) i M2 tipa makrofaga $(9,10)$. M2 makrofagi podržavaju angiogenezu i oslobađaju velike količine IL10 i VEGF. Pokazano je da M2 makrofagi ispoljavaju supresivne funkcije te predstavljaju i do $70 \%$ tumorpovezanih makrofaga kod bolesnika sa NSCLC $(9,10)$. Brojne studije pokazale dalje Th2 polarizaciju u raznovrsnim uzorcima kod obolelih od raka pluća. Uglavnom je utvrđen značajan porast IL-4 i IL10 zajedno sa smanjenjem IL2 i IFNG u uzorcima seruma $(11,12)$. Li i sar- su pokazali da je hirurško smanjenje tumora dovelo do smanjenja Th2 citokina i povećanja Th1 profila (13). Chen i suradnici su pokazali da mononuklearne ćelije periferne krvi kod brzo progredirajućih karcinoma sadrže veliku količinu IL-4 mRNA (14). Tu su i neka istraživanja koja su potvrdila da Th2 citokini dominiraju nad Th1 citokinima u uzorcima tkiva tumora i na proteinima mRNA. Naime, pleuralni izliv pacijenata obolelih od raka pluća sadrži značajne koncentracije IL-4 kao i koncentracije IL10 (15), bilo je IL-4 / IL10 / IL-2 iznad nivoa IL12 / Ifn-g u uzorcima od tumora pluća $(16,17)$, pa čak i tumor- infiltrišući limfociti su pokazali smanjeni sadržaj ili proizvodnju IFN- $\gamma(18)$. Sve ove studije su sprovedene kod bolesnika sa NSCLC. Vrlo retko su u istraživanjima uključene obe grupe bolesnika s karcinomom pluća. Chang i suradnici su istraživali vrednosti IL6 u uzorcima seruma iz SCLC i sva tri oblika NSCLC (19). Oni su pokazali da povećanje IL6 je povezano s brzim napretkom bolesti i lošim odgovorom na terapiju kod svih bolesnika sa LC. Oni su takođe pokazali da bolesnici sa squamocelularnim carcinomom imaju značajno veći IL6 u odnosu na adenokarcinom, ističući razliku vrednosti IL6 u ove dve grupe bolesnika saNSCLC.

Podaci koji se odnose na različit profil citokina između tumora pluća $\mathrm{s}$ različitim histološkim tipovima još uvek su rijetki. Naš cilj je bio da utvrdimo ključne Th1 i Th2 citokine, u tumorskoj mkrocirkulaciji i u uzorcima seruma, te da uporedimo profil citokina kod bolesnika s plućnim tumorima različitih histoloških tipova.

\section{MATERIJALI I METODE}

Pacijenti. U istraživanju je uključen 41 bolesnik, sa dijagnozom karcinoma pluća i 30 zdravih kontrola(Tablica 1). Bolesnici su bili dijagnostikovani i lečeni u Klinici za plućne bolesti, VMA, Beograd, Srbija, u razdoblju od marta do decembra 2014. Svi potrebni dijagnostički postupci (histološke, laboratorijske i radiološke analize), su obavljene na VMA u Beogradu. Svi bolesnici i kontrolna grupa zdravih su pristali i ova studija je odobrena od strane lokalnog etičkog komiteta za istraživanje, VMA (11-03 / 2014).

Uzorci. Uzorci krvi uzeti su iz kubitalne vene. Tumorski uzorci mikrocirkulacije uzeti su iz dostupnih patoloških krvnih sudova sa iglom, aspiracijom u dijagnostici za bronhoskopiju. Serum je odvojen iz uzorka nakon centrifugiranja (3000 g, $10 \mathrm{~min}, \mathrm{RT}$ ), te zamrznut na $-70{ }^{\circ} \mathrm{C}$ do ispitivanja. IL-2, IL-12, IFN- $\gamma$, IL-4, IL-5, IL-6, IL-10 i IL-13 $\mathrm{su}$ mereni citometrijskim testovima komercijalnih kitova (eBioscience kompletima) na Beckman Coulter protok cytometar FC500.

Statistička analiza. Svi statistički testovi izvedeni su sa softverom GraphPad Prism 5, korištenjem ANOVA testova (s Bonferroni nakon ispitivanja) za više grupa upoređivanja, Mann Whitney test za poređenje razlika između dveju nezavisnih grupa, Wilcoxon za poređenje uparenih (serum / tumor) uzoraka i Pearson korelacija testa.

\section{REZULTATI}

Citokini u sistemskoj cirkulaciji bolesnika $\mathrm{s}$ različitim histološkim karcinomima pluća

Uzorci pacijenata sa nesitnoćelijskim karcinomom (NSCLC) pokazuju najveću prosečnu koncentraciju IL2, znatno veću u odnosu na bolesnike sa squamoznim ili SCLC tipom tumora pluća (tablica 2), (Slika 1.). Najniža koncentracija IL-12 detektovana je u uzorcima kod pacijenata sa 
squamocelularnim tipom NSCLC značajno manja u odnosu na grupu sa SCLC. Bolesnici s NSCLC tumorima, adenokarcinom i karcinom velikih čelija, je imao najvišu prosečnu koncentraciju IFNG u uzorcima seruma. Suprotno, bolesnici sa squamocelularnim NSCLC imali su niže prosečne vrednosti IFNG. Najviša prosečna koncentracija IL4 je bila kod pacijenata $\mathrm{s}$ adenokarcinom (Ad NSCLC), nesignifikantno povišena $u$ drugim grupama. Pacijenati sa squamocelularnim karcinomom (sq NSCLC) su imali najmanju prosečnu vrednost IL5, znatno manju u odnosu na nesitnoćelijske karcinome NSCLC. Ova grupa, squamocelularnih karcinoma (Sq NSCLC) je imala vrlo povišene vrednosti IL 6, suprotno, gotovo nemerljiv IL6 kod bolesnika s adeno i karcinom velikih ćelija. Koncentracije IL13 su bile slične u uzorcima pacijenata koji su imali SCLC i adenokarcinom, gotovo dvostruko više nego u uzorcima bolesnika $\mathrm{s}$ drugim vrstama NSCLC. Prosječan nivo IL17 neznatno je povišen u uzorcima kod bolesnika sa adenokarcinomom, u odnosu na sve ostale grupe. Najviša prosečna koncentracija IL1b je otkrivena u uzorcima bolesnika sa SCLC, dok su bolesnici sa NSCLC imali najveću vrednost TNF. Bolesnici sa adenokarcinomom su imali najvišu prosečnu vrednost koncentracije IL9, značajno povišene $u$ odnosu na SCLC i squamocelularni NSCLC. Koncentracija IL22 bila prisutna $\mathrm{u}$ uzorcima iz svih ispitivanih grupa $\mathrm{s}$ najvišom prosječnom vrednošču u uzorcima pacijenata $\mathrm{s}$ tipom SCLC. Na kraju, bolesnici sa karcinomom velikih ćelija NSCLC imali su najvišu prosečnu vrednost koncentracije TGFb1, signifikantno više u poređenju sa svim ostalim grupama.

Analiza grupe Th1 citokina je pokazala da bolesnici sa squamocelularnim NSCLC ima najnižu prosečnu vrednost koncentracije IL2, vrednosti IL12 i IFNG, za razliku od bolesnika sa krupnoćelijskim NSCLC. Analiza Th2 citokina nije dala jasnu sliku. Bolesnici s krupnoćelijskim NSCLC koji su pokazali Th1 dominaciju imala je relativno nisku koncentraciju IL-4 i IL5, ali i najveću koncentraciju IL10. Bolesnike sa squamocelularnim NSCLC karakteriše niska vrednost Th1citokina, te je vrlo skroman nivo IL-4 i IL5, ali i visoke prosečne koncenacije IL6 . Bolesnici s adenokarcinoma su imali najviše prosečne vrijednosti IFNG i IL-4, zajedno s visokim nivoima IL10 i 13, i niskim vrijednostima IL-4 i IL5. Koncentracija IL-2, IL-12, IFNG, IL-4 i IL5 su izjednačene kod bolesnika s SCLC, ali s visokom nivoom IL13 uz visoku prosečnu vrednost IL6 koja je bila gotovo 20 puta veća u odnosu na vrednosti kod bolesnika sa adenokarcinomom krupnoćelijskim karcinomima NSCLC grupe.

Citokini u mikrocirkulaciji tumora kod bolesnika sa različitim histološkim tipovima karcinoma

Koncentracija citokina Th1, IL-2, IL-12 IFNG je bio je najviši u uzorcima bolesnika sa SCLC, IL-12 i IFNG su značajno viši u odnosu na bolesnike sa NSCLC (Tablica 3). (Slika 1.). Bolesnici sa SCLC, zajedno sa bolesnicima sa adenokarcinomima su imali najviše prosečne koncentracije IL-4 u uzorcima mikrocirkulacije tumora. Suprotno, bolesnici s sqamocelularnim karcinomom i krupnoćelijskim NSCLC su imali najvišu prosječnu koncentraciju IL5, signifikantno veću u odnosu na grupu bolesnika sa adenokarcinomom. Pacijenti sa krupnoćelijkim karcinomom su imali značajno nižu koncentraciju IL6 od svih drugih pacijenata. IL 6, kao i IL13 su izrazito povišeni kod bolesnika sa adenokarcinomom i SCLC. Pacijenti sa SCLCsu imali su vrednosti koncentracije IL10 značajno povišene $u$ odnosu na adenokarcinom $i$ squamocelualrni NSCLC. Bolesnici s pločastih i krupnoćelijskim NSCLC je imao znatno niže vrednosti IL17 u odnosu na bolesnike sa adenokarcinomom i SCLC. Bolesnici sa SCLC i adenokarcinomom su imali najviše koncentracije IL1b i TNF, znatno povišene u odnosu na bolesnike sa squamocelualrnim karcinomom i karcinomom velikih ćelija. Koncentracija IL9 je smanjen u uzorcima ispitivanih pacijenata, a najniže vrednosti su kod bolesnika sa squamocelularnim i krupnoćelijskim karcinomima, značajno su manje u odnosu na adenokarcinom i SCLC. Bolesnici sa SCLC su imali najvišu prosečnu koncentraciju IL22, značajno veće od svih ostalih pacijenata sa NSCLC. Pacijenti sa adenokarcinomom su imali najvišu prosečnu koncentraciju IL27, znatno povećanu u odnosu na SCLC i krupnoćelijske karcinome. Bolesnici sa squmocelularnim NSCLC imaju dramatično povećan nivo TGFb1, znatno povećan $\mathrm{u}$ odnosu na bolesnike sa SCLC i bolesnike sa kropnoćelijskim karcinomima.

Poređenje pojedinih citokina u mikrocirkulaciji tumora i sistemskoj cirkulaciji prema histološkim tipovima tumora 
Ova analiza je sprovedena poređenjem vrednosti koncentracije citokina u mikrocirkulaciji tumora i serumu svakog citokina u uzorcima bolesnika (Tablica 4). Bolesnici sa SCLC pokazuju čisto i značajno povećanje Th1 tipa citokina, IL-2, IL-12 IFNG i u njihovim uzorcima mikrocilkulacije $u$ tumoru. Sličan porast Th1 citokina je otkriven $u$ uzorcima bolesnika s sqamocelularnim NSCLC, ali sa značajnim porastom samo-IL12. Dok pacijenti s adenokarcinomima imaju povećan nivo IFNG i IL$12 \mathrm{u}$ tumorima bez promjene IL2, bolesnici $\mathrm{s}$ velikim čelijama NSCLC su imali značajno smanjenje citokina Th1 u tumorskoj mikrocirkulaciji. Jedan od ključnih Th2 citokina, IL4, povećan je u tumorskoj mikrocirkulaciji svih vrsta tumora, očekivano i kod bolesnika sa adenokarcinomom su pokazali sniženje za IL-4 u odnosu na nivoe u serumu. Svi pacijenti NSCLC pokazali porast IL5 u njihovoj tumorsoj mikrocirkulaciji, bez bilo kakve promene kod SCLC. IL6 je pokazao povećanje iz tumorskog tkiva pacijenata, ali samo značajno povećanje kod adenokarcinoma. Slično tome, IL13 pokazao porast u svim uzorcima tumora, ali značajno povećanje samo kod bolesnika sa SCLC i krupnoćelijkim karcinomom. IL10 značajno povećan u uzorcima tumora kod SCLC pacijenata, ali i sniženje kod NSCLC. IL17 je neznatno povišen u uzorcima tumora i adenokarcinoma i SCLC, te smanjen kod bolesnika sa squamocelularnim i krupnoćelijskim NSCLC. Upalni IL1b je značajno povećan u svim uzorcima osim squamocelualrnog karcinoma. Značajno povećan nivo u mikrocirkulaciji tumora je bio za TNF, karakteristično za SCLC i adenokarcinome, ali ne i druge vrste. Zanimljivo je da je IL22 koji se smatra protumorogenim citokinom, pokazao neznatno sniženje u svim uzorcima tumora bez obzira na histološki tip. Isto tako, IL9 je smanjen kod svih bolesnika sa značajnom padom kod adeno i krupnoćelijskih NSCLC. IL27 je pokazao porast u tumorskoj mikrocirkulaciji kod svih bolesnika, sa značajnim nivoom kod adeno i krupnoćelijskog NSCLC. Konačno, TGFb1 je povećan u lokalnoj cirkulaciji tumora samo kod squamocelualrnog NSCLC, dok su svi ostali pokazali značajno smanjenje tog citokina.

\section{DISKUSIJA}

Postoje sukobljeni podaci o Th1 / TH2 profilu citokina koji su određeni u uzorcima pacijenata $\mathrm{s}$ rakom pluća. Asselin-Paturel i sur. su prvi koji pokazali da tumorsko tkivo kod pacijenata s NSCLC sadrži visok nivo IL-6, IL-10, GM-CSF i IFNg uz nizak nivo IL-2 mRNK (3). Takođe su pokazali da $60 \%$ perifernih limfocita istih bolesnika sadrži visoku IL6 mRNA. Iako je IFNg mRNK jasno prisutan $\mathrm{u}$ uzorcima tumorskog tkiva, autori zaključuju da profil Th2 citokina dominira kod bolesnika sa NSCLC, i lokalno i sistemski. Studija Li i suradnika (16) pokazala je veću ekspresiju Th2 nego Th1 citokina na nivou mRNA $u$ biopsiji tumora pluća i pleuralnim izlivima bolesnika sa NSCLC (IL4 i IL10 vs IL2, IL12, IFNg). Wei i sar. su proučavali odnos koncentracija Th1 / Th2 u serumima bolesnika $\mathrm{s}$ NSCLC i pokazali su smanjenje IL2 i IFNg uz povećanu koncentraciju IL4 i IL6 (11). Ma i sar. su pokazali isti nalaz, Th2 dominantnost u perifernoj krvi NSCLC bolesnika (12). Ispitivali su učinke torakoskopske primene autolognih dendritičnih čelija podstaknutih antigenom tumora sa ili bez pripreme ginseng polisaharida na Th1 / Th2 odnos. Oni su izvestili da je ovaj tretman indukovao povećanje IFNg / IL2 ekspresije, a smanjuje IL4 / IL5 ekspresiju. Iako je studija sprovedena na samo 5 bolesnika, Hodge i saradnici pokazali su da CD8 $+\mathrm{T}$ limfociti, NK i NKT ćelije iz njihovih tumora pluća pokazuju značajno smanjenje kapaciteta za proizvodnju citotoksičnih medijatora (perforin, granzyme B), takođe i nizak nivo proizvodnje IFNg (18). Grupa Jun Li je izvestila o smanjenju Th1 citokina $\mathrm{u}$ poređenju $\mathrm{s}$ Th2 $\mathrm{u}$ serumskim uzorcima NSCLC bolesnika (13). Kod operisanih bolesnika hirurško odstranjenje tumorskog tkiva izazvalo je povećanje IL2 i IFNg, uz smanjenje koncentracije IL4 i IL10. Dodatno, ova grupa je pokazala da je dugo vreme povećanja koncentracije IL4 kod bolesnika s NSCLC značajno povezano s progresijom bolesti, vremenom preživljavanja i stopom smrtnosti. Th2 profil citokina mogao bi kritički promeniti fenotip i funkcije makrofaga, pretvarajući ih u tip M2 koji ispoljavaju procese tumorogenih aktivnosti. Zhang i suradnici su pokazali da je dominantna populacija makrofaga $(>75 \%) \mathrm{u}$ tumorskom tkivu NSCLC bolesnika M2 tipa (17). Oni su pretpostavili da bi ovo skretanje TH2 moglo biti povezano s visokim 
nivoom odnosa IL4 / IL10 i niskom koncentracijom IFNg / IL12 pronađenih u tumorskom tkivu u poređenju s benignim lezijama. Istraživanje Ito i sar. je pokazalo najopsežniju sliku različitih profila citokina u $\mathrm{T}$ limfocitima pacijenata s rakom pluća, NSCLC tipa (20). Njihovo ispitivanje je pokazalo da su limfociti koji infiltrišu tumor (TIL) uglavnom Th1, suprotno dominantnom nalazu Th2 populacije u uzorcima periferne krvi istih bolesnika s NSCLC. Proširili su svoju studiju na citotoksičnim $T$ limfocitima oba profila, naime Tc1 i Tc2, te su izvestili o rezultatima studije $\mathrm{s}$ rezultatom petogodišnjeg praćenja pacijenata (21). Nizak Th1 / Th2, kao i nizak Tk2 / Tc2 citokinski profil u uzorcima periferne krvi bio je povezan s boljom prognozom u NSCLC bolesnika. Ne može se povezati profil specifičnog citokina u $\mathrm{T}$ limfocitu sa nižim patološkim stadijumom bolesti (Stadijum I), ali kod bolesnika koji su bolovali od uznapredovale bolesti (stadijuma II i III), nizak nivo odnosa Th1 / Th2 značajno korelira s boljom prognozom.

Naša je studija uključila i bolesnike sa SCLC i NSCLC, suprotno svim studijama sprovedenim uglavnom na uzorcima bolesnika sa NSCLC. Analiza uzoraka seruma pokazala je najveću prosečnu koncentraciju IFNg u uzorcima bolesnika s NSCLC (adenokarcinom i karcinomom velikih ćelija NSCLC). Analiza uzoraka mikrocirkulacije tumora pokazala je potpuno drugu situaciju. Najveća prosečna koncentracija IFNg detektovana je kod bolesnika sa SCLC, i značajno je povećana u odnosu na sve histološke tipove NSCLC. Među NSCLC pacijentima, oni koji imali karcinom velikih ćelija, imali su najnižu vrednost IFNg. Nadalje, otkrili smo da je IFNg povećan u mikrocirkulaciji tumora u poređenju s uzorkom seruma značajno kod bolesnika sa SCLC, nesingnifkantno je povećan kod bolesnika $s$ adenokarcinomom i skvamoznim tumorima, ali je značajno smanjen kod bolesnika $\mathrm{s}$ karcinomom velikih ćelija.

Analiza ekspresije gena PBMC kod bolesnika s NSCLC pomoću microarraya pokazala je značajne promene gena povezanih s funkcijom IL4, što znači da su progresori izrazito obogaćivali ekspresiju IL4 profila (14). Uspešna hemoterapija negativno je regulisala te gene. Podaci iz eksperimentalne studije pokazali su da IL4 indirekto indukuje neoplastičnu proliferaciju plućnih ćelija, stimulišući makrofage povezane $\mathrm{s}$ tumorima kako bi se proizveo IGF1 lokalno (22). Istraživanje citokinskih profila $\mathrm{u}$ uzorcima pleuralne tečnosti kod bolesnika $\mathrm{s}$ malignim tumorima, ekstratorakalnih tumora, tuberkuloze i hroničnih kongestivnih izliva zbog srčane slabosti, otkrili su impresivan ali nespecifičan pomak od TH1 do TH2 profila (15). Autori su pronašli da se nivo IFNg smanjuje kod svih malignih uzoraka izliva, zajedno s povećanjem IL4 i IL10. Najvredniji rezultati dolaze iz istraživanja Gocheva grupe, koja je utvrdila izvor IL4 u uzorcima tumora bolesnika. Gocheva je pokazala da je lokalno proizvedeni IL4 važan u induciranju makrofaga povezanih $\mathrm{s}$ tumorom kako bi se dobio M2 polarizovani fenotip i povećala aktivnost katepsina, što bi moglo podstaći tumorske ćelije da napadnu susedno tkivo (23). Izvor intratumorskog IL4 su oba tipa T tumorskih limfocita. Dok T ćelije obilno proizvode IL4, proizvode samo $2 \%$ populacije IL4 suprotno tumorskim ćelijama koje sadrže $80-85 \%$ ćelija koje proizvode IL4. IL4 je povećan u uzorcima tumora u našoj grupi bolesnika s SCLC, kao i u uzorcima pacijenata sa skvamoznim i velikim ćelijama NSCLC. Pacijenti s adenokarcinom su pokazali smanjenje IL4 u tumoru u poređenju s uzorcima seruma.

Istraživanje $\mathrm{CD} 8+\mathrm{T}$ limfocita specifičnih za tumorske antigene kod 3 bolesnika sa SCLC su potvrđene dve vrste ćelija, klasičan IFNg koji proizvodi $\mathrm{CD} 8+\mathrm{T}$ citotoksični limfocit za tumorske ćelije i "ne-klasičnu" ne-citotoksičnu CD8 + T populaciju koja proizvodi IL5 i IL13 kao odgovor na tumor antigene (24). Autori su nadalje pokazali da SCLC tumorske ćelije luče Th2 citokine, što bi moglo podstaći lokalnu Th2 dominaciju i razvoj tumorski specifičnih CD8 $+\mathrm{T}$ ne-citotoksičnih Th2 T limfocita. Eozinofili imaju dvostruku ulogu u karcinogenezi i nadzoru tumora. $\mathrm{U}$ ranoj fazi rasta tumora eozinofili kao i Th posrednici pokazuju anti-tumorske funkcije. U terminalnim fazama sa tumorskim rastom, infiltrirani eozinofili koji reagiraju na IL5 podržavaju rast $i$ širenje tumora. Analizirane vrednosti IL5 u uzorcima naših pacijenata pokazale su uočljive razlike. Pacienti s velikim ćelijama NSCLC-a imali su jasno povišenu vrednost serumskog IL5, dok su drugi imali slične prosečne koncentracije. Suprotno tome, IL5 je značajno povećan u uzorcima tumorske mikrocirkulacije NSCLC pacijenata, posebno onih $\mathrm{s}$ squamo i velikim tumorskim ćelijama, ali bez ikakvih promjena u grupi sa SCLC tipom tumora. 
Istorijski rad Yanagawe je pokazao da je IL6 povišen $\mathrm{u}$ serumskim uzorcima pacijenata $\mathrm{s}$ rakom pluća, a autori su pretpostavili da ovaj citokin može biti jedan od glavnih posrednika pothranjenosti (25). Nedavni eksperimentalni podaci dali su dokaze o ulozi IL6 u tumorskoj genezi adenokarcinoma pluća (26). Istraživanje 72 bolesnika s SCLC pokazalo je da bolesnici s ekspanzivnim oblikom SCLC-a imaju značajno povećanje nivoa IL6 u poređenju s onima s ograničenom bolesti (27). Ti su autori istakli da grupa bolesnika $\mathrm{s}$ visokom koncentracijom IL6 takođe ima povišenu koncentraciju VEGF. Bolesnici s karcinomom pluća sa skvamoznim tipom i visokim serumom IL6 imali su dvostruko kraći period preživljavanja u poređenu s onima koji su imali visok IL6 i adenokarcinomom (21 vs 37 mjeseci) (19). Nadalje, bolesnici s visokom nivoom serumskog IL6 reagovali su slabo na radio i hemoterapiju, a napredovali su u kraćem vremenskom intervalu za razliku od bolesnika $\mathrm{s}$ niskim / posredovanim IL6. Na temelju tih podataka iz odvojenih studija, visoki nivoi IL6 su povezani sa uznapredovalom bolešću kod SCLC i NSCLC bolesnika. U našem istraživanju bolesnici sa skvamoznim karcinomom i SCLC bolesnici imali su najveći nivo serumskog IL6 u poređenju s drugim tipovima karcinoma pluća. Analiza IL6 u mikrocirkulaciji tumora je pokazala dramatično povećanje IL6 u uzorcima bolesnika s SCLC i adenokarcinom u poređenju sa serumskim koncentracijama, $\mathrm{s}$ praktično identičnom koncentracijom IL6 kod karcinoma skvamoznih i velikih ćelija. Vredno je istaći da su pacijenti sa karcinomom velikih ćelija imali najmanju koncentraciju IL6 (i serumu i tumoru) u poređenju sa svim ostalim vrstama.

Pored CD4 Th2 ćelija, tumorska ćelija može steći sposobnost proizvodnje IL13. Istraživanje Huanga je pokazalo da su tumorske plućne ćelije moćni proizvođači IL13 (28). Huang i sar. su analizirali proizvodnju citokina iz 5 nscLC tumorskih ćelijskih linija, pokazujući da svi proizvedeni IL5 i IL10, 60\% njih izlučuje IL4, 40\% proizvodi IL13 i niko nije proizveo Th1 citokine, IFNg i IL2. Nadalje, istraživali su 13 bolesnika NSCLC i imunohistohemijski su pokazali da su ćelije tumora izvor IL13. Fujisawa grupa dodatno je naglasila ulogu IL13 u regulaciji invazije i širenja raka (29,30). Naši bolesnici s SCLC tumorima imali su najveću prosečnu vrednost IL13, posebno u mikrocirkulaciji tumora. IL13 je citokin svih ispitivanih čija je koncentracija značajno povećana $u$ uzorcima tumora svih bolesnika $\mathrm{u}$ poređenju $\mathrm{s}$ serumskim vrednostima, bez obzira na histološki tip tumora.

\section{ZAKLJUČAK}

Postoji ranije utvrđeno mišljenje da je Th1 tip odgovora važan protiv tumora, dok Th2 negativno utiče na antitumorski odgovor. To bi moglo biti pojednostavljeno $\mathrm{u}$ razumevanju anti-tumorskog odgovora, budući da svi ovi citokini moglu delovati i kao pro ili anti tumorski, u zavisnosti od individualnih karakteristika tumora, stadijuma bolesti i karakteristika imunološkog odgovora. $\mathrm{Na}$ temelju koncentracije citokina postoji dramatična i značajna razlika između dva odeljka, sistemske cirkulacije i mikrocirkulacije tumora. Tumori pluća s različitim histološkim tipovima značajno se razlikuju među sobom u pogledu Th1 i Th2 citokinskog profila.

\section{LITERATURA:}

1. Dela Cruz CS, Tanoue LT, Matthay RA. Lung cancer: epidemiology, etiology, and prevention. Clin Chest Med 2011;32:605-44.

2. Travis WD, Brambilla E, Riely GJ. New pathologic classification of lung cancer: relevance for clinical practice and clinical trials. J Clin Oncol 2013;31:992-1001.

3. Asselin-Paturel, Echchakir H, Carayol G, Gay F, Opolon P, Grunenwald D, et al. Quantitative analysis of Th1, Th2 and TGF-beta1 cytokine expression in tumor, TIL and PBL of non-small cell lung cancer patients. Int J Cancer. 1998; 77(1):7-12.

4. Fischer JR, Darjes H, Lahm H, Schindel M, Drings $\mathrm{P}$, Krammer PH. Constitutive secretion of bioactive transforming growth factor beta 1 by small cell lung cancer cell lines. Eur J Cancer 1994;30A(14):21259.

5. Bennett WP, el-Deiry WS, Rush WL, Guinee DG Jr, Freedman AN, Caporaso NE, et al. p21waf1/cip1 and transforming growth factor beta 1 protein expression correlate with survival in non-small cell lung cancer. Clin Cancer Res 1998;4:1499-506.

6. Domagała-Kulawik J, Hoser G, Safianowska A, Grubek-Jaworska H, Chazan R. Elevated TGFbetal concentration in bronchoalveolar lavage fluid from patients with primary lung cancer. Arch Immunol Ther Exp (Warsz) 2006;54:143-7. 
7. Andreev K, Graser A, Maier A, Mousset S, Finotto S. Therapeutical measures to control airway tolerance in asthma and lung cancer. Front Immunol 2012;3(Article 216):1-13.

8. Través PG, Luque A, Hortelano S. Macrophages, inflammation, and tumor suppressors: ARF, a new player in the game. Mediators Inflamm 2012;2012(Article 568783):1-11.

9. Mantovani A, Sozzani S, Locati M, Allavena P, Sica A. Macrophage polarization: tumor-associated macrophages as a paradigm for polarized M2 mononuclear phagocytes. Trends Immunol 2002;23:549-55.

10. Liu L, Ge D, Ma L, Mei J, Liu S, Zhang Q, et al. Interleukin-17 and prostaglandin E2 are involved in formation of an M2 macrophage-dominant microenvironment in lung cancer. J Thorac Oncol 2012;7:1091-100.

11. Wei H, Sun R, Xiao W, Feng J, Zhen C, Xu X, et al. Type Two Cytokines Predominance of Human Lung Cancer and Its Reverse by Traditional Chinese Medicine TTMP. Cellular \& Molecular Immunology 2004;1(1):63-70.

12. Ma J, Liu H, Wang $X$. Effect of ginseng polysaccharides and dendritic cells on the balance of Th1/Th2 $\mathrm{T}$ helper cells in patients with non-small cell lung cancer. J Tradit Chin Med 2014; 34(6): 641-645.

13. Li J, Wang Z, Mao K, Guo X. Clinical significance of serum $\mathrm{T}$ helper $1 / \mathrm{T}$ helper 2 cytokine shift in patients with Hon-small cell lung cancer. Oncology Letters 2014;8: 1682-1686.

14. Chen YC, Hsiao CC, Chen KD, Hung YC, Wu CY, Lie $\mathrm{CH}$ et al. Peripheral Immune Cell Gene Expression Changes in Advanced Non-Small Cell Lung Cancer Patients Treated with First Line Combination Chemotherapy. PLoS ONE 2013; 8(2): e57053. doi:10.1371/journal.pone.0057053

15. Ghayumi MA, Mojtahedi Z, Fattahi MJ. Th1 and Th2 Cytokine Profiles in Malignant Pleural Effusion. Iran J Immunol 2011; 8 (4), 195-200.

16. Li R, Ruttinger D, Li R, Si LS, Wang YL. Analysis of the immunological microenvironment at the tumor site in patients with non-small cell lung cancer. Langenbeck's Archives of Surgery 2003;388(6)406412.

17. Zhang B, Yao G, Zhang Y, Gao J, Yang B, Rao Z, et al. M2-Polarized tumor-associated macrophages are associated with poor prognoses resulting from accelerated lymphangiogenesis in lung adenocarcinoma. Clinics 2011;66(11):1879-1886.

18. Hodge G, Barnawi J, Jurisevic C, Moffat D, Holmes $\mathrm{M}$, Reynolds PN et al. Lung cancer is associated with decreased expression of perforin, granzyme B and interferon (IFN)- $\gamma$ by infiltrating lung tissue $\mathrm{T}$ cells, natural killer (NK) T-like and NK cells. Clinical and Experimental Immunology 2014; 178: 79-85.

19. Chang $\mathrm{CH}$, Hsiao CF, Yeh YM, Chang GC, Tsai $\mathrm{YH}, \mathrm{Chen} \mathrm{YM}$ et al. Circulating interleukin-6 level is a prognostic marker for survival in advanced nonsmall cell lung cancer patients treated with chemotherapy. Int J Cancer 2013; 132: 1977-1985.

20. Ito $\mathrm{N}$, Nakamura $\mathrm{H}$, Metsugi $\mathrm{H}$ and Ohgi $\mathrm{S}$. Dissociation between $\mathrm{T}$ helper type $1 /$ type 2 differentiation and cytokine production of tumorinfiltrating lymphocytes in lung cancer patients. Surg Today 37: 390-394, 2001.

21. Ito N, Suzuki Y, Taniguchi Y, Ishiguro K, Nakamura $\mathrm{H}$, Ohgi S. Prognostic significance of T helper 1 and 2 and $\mathrm{T}$ cytotoxic 1 and 2 cells in patients with nonsmall cell lungcancer. Anticancer Res. 2005;25(3B):2027-31.

22. Fritz JM, Dwyer-Nield LD and Malkinson MA. Stimulation of neoplastic mouse lung cell proliferation by alveolar macrophage-derived, insulin-like growth factor-1 can be blocked by inhibiting MEK and PI3K activation. Molecular Cancer 2011; 10:76.

23. Gocheva V, Wang HW, Gadea BB, Shree T, Hunter $\mathrm{KE}$, Garfall $\mathrm{AL}$ et al. IL-4 induces cathepsin protease activity in tumor-associated macrophages to promote cancer growth and invasion. Gene \& Development 2010; 24:241-255.

24. Roberts WK, Deluca IJ, Thomas A, Fak J, Williams $\mathrm{T}$, Buckley $\mathrm{N}$ et al. Patients with lung cancer and paraneoplastic $\mathrm{Hu}$ syndrome harbor HuD-specific type 2 CD8+ T cells. J Clin Invest 2009; 119:20422051. doi:10.1172/JCI36131.

25. Yanagawa H, Sone S, Takahashi Y, Haku T, Yano S, Shinohara T, et al. Serum levels of interleukin 6 in patients with lung cancer. Br J Cancer 1995; 71: 1095-1098.

26. Zhao Z, Cheng $\mathrm{X}$, Wang $\mathrm{Y}$, Han $\mathrm{R}$, Li L, et al. Metformin Inhibits the IL-6-Induced EpithelialMesenchymal Transition and Lung Adenocarcinoma Growth and Metastasis. PLoS ONE 2014; 9(4): e95884. doi:10.1371/journal.pone.0095884.

27. Wójcik E, Jakubowicz J, Skotnicki P, SasKorczyńska B, Kulpa JK.IL-6 and VEGF in Small Cell Lung Cancer Patients. Anticancer Research 2010; 30: 1773-1778.

28. Huang M, Wang J, Lee P, Stiantila S, Mao JT, Meissner $\mathrm{H}$ et al. Human Non-Small Cell Lung Cancer Cells Express a Type 2 Cytokine Pattern. Cancer Research 1995; 55: 3847-3853. 
29. Fujisawa T, Joshi B, Nakajima A, Puri RK. A Novel Role of Interleukin-13 Receptor $\alpha 2$ in Pancreatic Cancer Invasion and Metastasis. Cancer Res 2009;69(22):8678-85.
30. Fujisawa T, Joshi BH, Puri RK IL-13 regulates cancer invasion and metastasis through IL-13Ra2 via ERK/AP-1 pathway in mouse model of human ovarian cancer. Int. J. Cancer 2012, 131: 344-356.

Slika 1. Prosečna vrednost ispitivanih citokina u uzorcima različitih grupa bolesnika prema histologiji tumora pluća. SCLC grupa, A.- serumskih uzoraka, B.- uzorci iz mikrocirkulacije tumora. NSCLC adenokarcinomi, C. serum, D.- uzorci iz mikrocirkulacije tumora. Squamozni NSCLC, E. serumski uzorci, F.- uzorci iz mikrocirkulacije tumora. NSCLC karcinom velikih ćelija, G.-serumski uzorci, H.- uzorci iz mikrocirkulacije tumora.
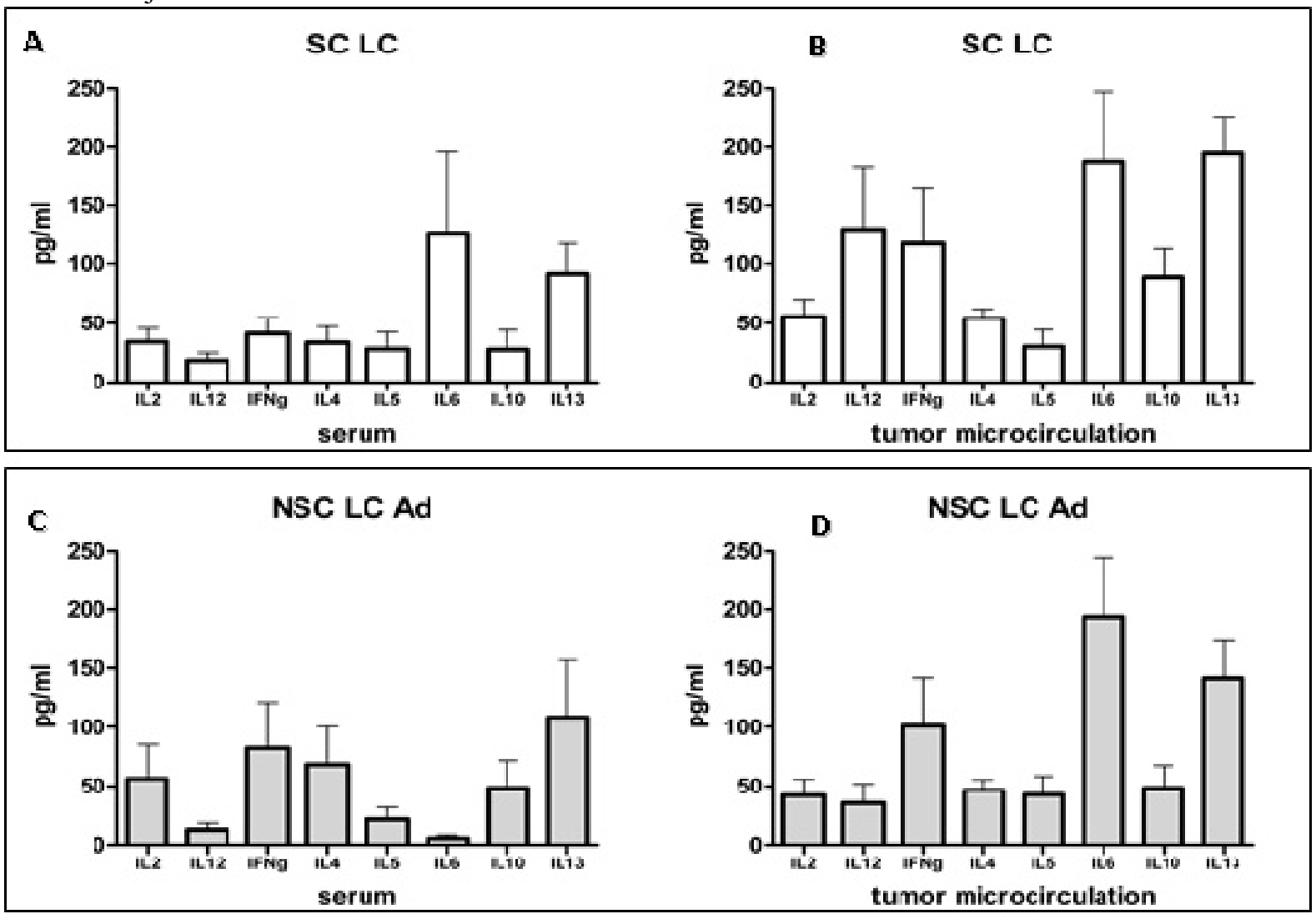

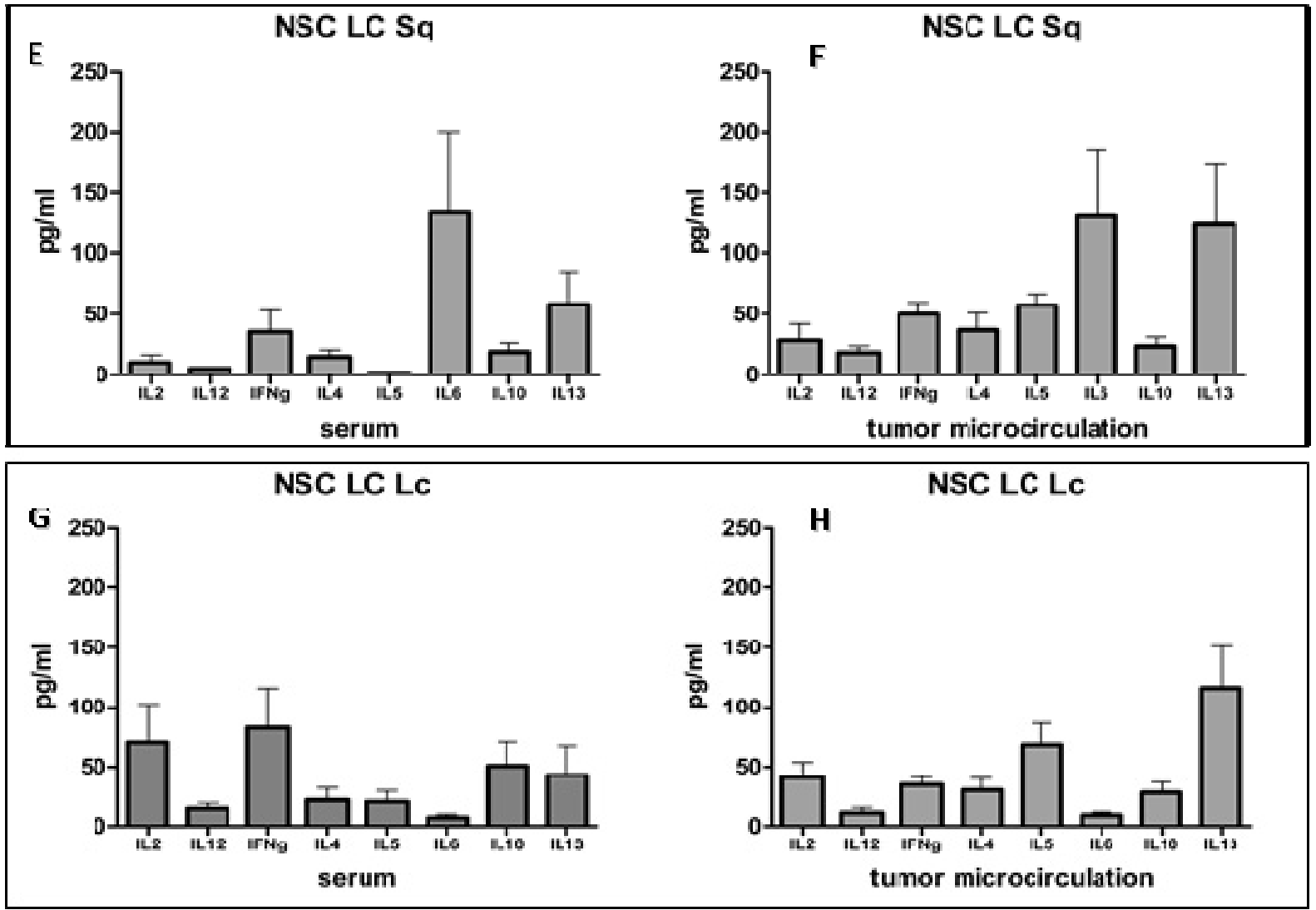

Slika 1. Legenda.

Analiza uzoraka seruma pokazala je jasnu razliku u vrednostima Th1 citokina. Pacijenti s NSCLC Lc i NSCLC ad su imali najveću vrednost odnosa Th1/Th2, dok su SCLC i NSCLC sq imali visok nivo serumskog IL6 i IL13. Uporedna analiza uzoraka mikrocirkulacije tumora pokazala je sasvim drugačiju situaciju. Suprotno svim ostalim grupama $i$ suprotno serumskim uzorcima istih bolesnika sa SCLC, bolesnici sa SCLC su imali visoke vrednosti IL2, IL12, IFNg, IL4, IL10 i IL13. S druge strane, bolesnici sa NSCLC imaju različit profil lokalnih citokina. Bolesnici iz NSCLC Ad grupe imaju visok IL12 i IL6, bolesnici s NSCLC Sq grupe imaju visoke vrednosti IL12 i IL5, dok su oni iz grupe

NSCLC Lc postigli signifikantno povećane vrednost IL5 i IL13 u poređenju s njihovim serumskim uzorcima.

\begin{tabular}{|c|c|c|c|}
\hline \multicolumn{4}{|c|}{ Tabela 1. Karakteristike bolesnika } \\
\hline Subjects and Characteristics & Variables & & $\begin{array}{c}N \\
(\mathrm{x} \pm \mathrm{SD})\end{array}$ \\
\hline Healthy controls & $\begin{array}{c}\text { Male } \\
\text { Female } \\
\text { Age, years }(x \pm S D)\end{array}$ & & $\begin{array}{c}22 \\
8 \\
57 \pm 14\end{array}$ \\
\hline Patients & $\begin{array}{c}\text { Male } \\
\text { Female } \\
\text { Age, years }(x \pm S D)\end{array}$ & & $\begin{array}{c}31 \\
10 \\
62 \pm 8\end{array}$ \\
\hline Histological types & $\begin{array}{l}\text { NSCLC } \\
\text { NSCLC } \\
\text { NSCLC } \\
\text { SCLC }\end{array}$ & $\begin{array}{c}\text { adenocarcinoma } \\
\text { squamous cell carcinoma } \\
\text { large cell carcinoma }\end{array}$ & $\begin{array}{c}13 \\
9 \\
10 \\
9\end{array}$ \\
\hline Clinical TNM stage & $\begin{array}{l}\text { III } \\
\text { IV }\end{array}$ & & $\begin{array}{l}24 \\
17\end{array}$ \\
\hline
\end{tabular}




\begin{tabular}{|llc|}
\hline Metastases & M0 & 27 \\
& M1 & 14 \\
\hline Tumor size & T1 & 7 \\
& T2 & 15 \\
& T3 & 12 \\
\hline
\end{tabular}

Tabela 2. Poređenje koncentracije citokina u sistemskoj cirkulaciji kod bolesnika različitih histoloških tipova

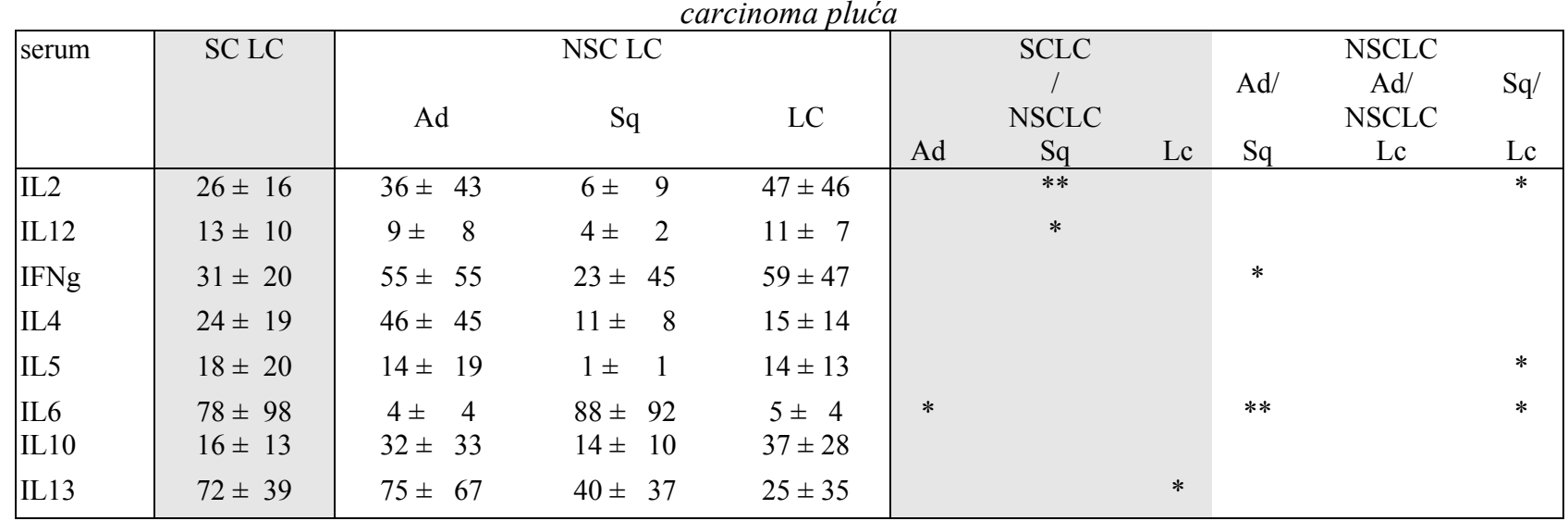

Tabela 3. Poređenje koncentracije citokina u mikrocirkulaciji tumora u zavisnosti od histološkog tipa carcinoma pluća.

\begin{tabular}{|c|c|c|c|c|c|c|c|c|c|c|}
\hline \multirow[t]{3}{*}{ tumor } & \multirow[t]{3}{*}{ SC LC } & \multicolumn{3}{|c|}{ NSC LC } & \multirow{2}{*}{\multicolumn{3}{|c|}{$\begin{array}{c}\text { SCLC } \\
/ \\
\text { NSCLC }\end{array}$}} & \multicolumn{3}{|c|}{ NSCLC } \\
\hline & & \multirow[t]{2}{*}{ Ad } & \multirow[t]{2}{*}{$\mathrm{Sq}$} & \multirow[t]{2}{*}{$\mathrm{LC}$} & & & & $\mathrm{Ad} /$ & $\mathrm{Ad} /$ & $\mathrm{Sq}$ \\
\hline & & & & & Ad & $\mathrm{Sq}$ & $\mathrm{Lc}$ & $\mathrm{Sq}$ & $\mathrm{Lc}$ & $\mathrm{Lc}$ \\
\hline IL2 & $46 \pm 20$ & $32 \pm 20$ & $19 \pm 19$ & $31 \pm 19$ & & & & & & \\
\hline IL12 & $92 \pm 77$ & $24 \pm 23$ & $15 \pm 7$ & $8 \pm 6$ & $*$ & $*$ & $*$ & & & \\
\hline IFNg & $87 \pm 64$ & $72 \pm 58$ & $43 \pm 14$ & $30 \pm 9$ & $*$ & $*$ & $* *$ & & & \\
\hline IL4 & $49 \pm 11$ & $40 \pm 13$ & $27 \pm 20$ & $23 \pm 14$ & & $*$ & $*$ & & & \\
\hline IL5 & $20 \pm 20$ & $31 \pm 23$ & $51 \pm 13$ & $55 \pm 26$ & & $*$ & $*$ & & $*$ & \\
\hline IL6 & $146 \pm 125$ & $158 \pm 155$ & $93 \pm 80$ & $7 \pm \quad 4$ & & & $* * *$ & & $* * *$ & $* *$ \\
\hline IL10 & $71 \pm 36$ & $35 \pm 27$ & $18 \pm 11$ & $22 \pm 12$ & * & $*$ & & $*$ & & \\
\hline IL13 & $173 \pm 44$ & $118 \pm 47$ & $90 \pm 70$ & $91 \pm 50$ & * & * & $* *$ & & & \\
\hline
\end{tabular}

Tabela 4. Analiza odnosa koncentracije citokina u mikrocirkulaciji tumora i u serumu kod bolesnika sa različitim histološkim tipovima karcinoma pluća (odnos tumor/serum).

\begin{tabular}{|c|c|c|c|c|}
\hline & \multirow[t]{2}{*}{ SCLC } & \multicolumn{3}{|c|}{ NSC LC } \\
\hline & & Ad & $\mathrm{Sq}$ & LC \\
\hline IL2 & $\Delta *$ & $=\nabla$ & $\Delta$ & $\nabla$ \\
\hline IL12 & $\Delta *$ & $\Delta *$ & $\Delta * *$ & $\nabla$ \\
\hline IFNg & $\Delta *$ & $\Delta$ & $\Delta$ & $\nabla$ \\
\hline IL4 & $\Delta *$ & $\nabla$ & $\Delta$ & $\Delta$ \\
\hline IL5 & $=$ & $\Delta$ & $\mathbf{\Delta}^{*}$ & $\Delta * *$ \\
\hline IL6 & $\Delta$ & $\Delta * *$ & $\Delta$ & $\Delta$ \\
\hline IL10 & $\Delta *$ & $\Delta$ & $\Delta$ & $\nabla$ \\
\hline IL13 & $\Delta * *$ & $\Delta$ & $\Delta$ & $\Delta * *$ \\
\hline
\end{tabular}


Abstract: Introduction. Lung cancer represents one of the most lethal malignancies, with minimal total survival rate in patients with advanced disease. According to histological structure they are classified as SCLC and NSCLC, group of tumors that differ significantly in biological behavior, clinical course and outcome, and potential to response to therapy. There is a previously established opinion that Th1 type is important in anti tumor response while Th2 negatively affects protective response. Data concerning difference of cytokine profile between lung tumors with different histological characteristics is still scarce.

Aim. Our objective was to investigate key Th1 and Th2 cytokines both in tumor microenvironment and serum samples, and to compare cytokine profiles between patients with lung tumors of different histological characteristics.

Material and methods. The study included 41 lung tumor patients in III and IV clinical stage. Histological type was determined immunohistochemically, while tumor size, localization and dissemination were determined radiologically. IL-2, IL-12, IFN- , IL-4, IL-5, IL-6, IL-10 and IL-13 concentrations were quantified with commercial flow cytometric test in serum and lung tumor microcirculation samples.

Results. Comparative analysis of serum cytokines in lung cancer patients demonstrated that group with SCLC tumors had significant IL-6 and IL-13 concentration. NSCLC group of patients showed different dominant cytokine profiles. Samples of patients with NSCLC Ad contained high levels of IL-2, IFN- , IL-4, IL-10 and IL-13, patients with NSCLC Sq had high IL-6 and IL-13, while patients with NSCLC LC had high IL-2 and IFN- . Cytokine profile in direct tumor microenvironment, tumor microcirculation, was completely different from profile estimated in sera samples. Tumor samples from SCLC patients were characterized with high IL-12, IFN- , IL-6 and IL-13. NSCLC Ad patients had high IFN- , IL-6 and IL-13, NSCLC Sq patients had high IL-6 and IL-13, while NSCLC LC had high IL-5 and IL-13. Analysis of investigated cytokines in both compartments of same patient revealed distinct tumor/serum ratio that are characteristic for distinct tumor histological types. Patients with SCLC tumors had significantly increased IL-2, IL-12, IFN- , IL-4, IL-10 and IL-13 tumor /serum ratio. NSCLC Ad had Significantly increased IL-12 and IL-6, NSCLC Sq had increased IL-12 and IL-5, while NSCLC $L C$ had significantly increased IL-5 and IL-13 tumor/serum ratio.

Conclusion. Lung tumors with different histological characteristics differ significantly among themselves in the aspect of detected Th1 and Th2 cytokine profile. Based on cytokine concentration there is dramatic and significant difference among two compartments, systemic circulation and tumor microenvironment.

V. Karličić

Klinika za plućne bolesti,

VMA, Beograd, Srbija

vukoica.karlicic@gmail.com

+381637750096 